\title{
EFEKTIVITAS PEMUNGUTAN PAJAK PENERANGAN JALAN DAN KONTRIBUSINYA TERHADAP PENDAPATAN ASLI DAERAH KOTA BANDUNG
}

\author{
Oleh: \\ Aristanti Widyaningsih \\ (Dosen Program Studi Akuntansi Fakultas Pendidikan Ekunomi \& Bisnis UPI)
}

\begin{abstract}
One of the prominent characteristics in a region to encomplish autonomy lies on its region's financial capability: Otherwise, the proportion or Region Original Income contribution to the regional income is decreasing although the nominal was increase. It is almost occurred in all residence or ciny in Indonesian, including Bandung City. Otherwise, Bandung is one of the city which has high value of Gross Domestic Regional Product (GDRP). The biggest contribution of Region Original Income in Bandung is regional tax. One of the regional tax is Lighting Tax Road. It is one of the biggest donation in regional income. This tax was exist in the second positioning of biggest contributor in 2001 until 2007 after the regional autonomy was prevail. Moreover, its has been existed in the third and first positioning. This study is intended to find out Lighting Tax Road after the effectiveness of region's autonomy unti! 2007. The method applied in this study is descriptive analysis by using single variable. Analysis was conducted to the potency, effectiveness, tax effort, elasticity, growth rate, contribution and times series analysis. According to result of Lighting Tar Road income, it can be inferred that income potency is increasing each year. The average of collection effectiveness is $68,35 \%$. The average of tax effort is 0,0022 (GDRP constant price) and 0,0011 (GDRP available price). The arerage of its elasticity is 1,76\% (GDRP constant price) and 0,94\% (GDRP available price). The average of growth rate each year is $20,09 \%$. The average of its contribution to region's tax is $25,53 \%$ and to Region Original Income is $15,56 \%$. And if the analysis of times series is used in this study, it can be predicted that the income will be increasing. Finally; it can be concluded that Lighting Tax Road is compatible for being the source of region;s income. Therefore, the government of Bandung should be consistant in optimazing tax management through Dipenda by collaborated with PT. PLN APJ Bandung.
\end{abstract}

Keyword : PAD, Pajak Daerah, Pajak Penerangan Jalan

\section{Latar Belakang}

Dalam rangka meningkatkan kemampuan keuangan daerah agar dapat melaksanakan otonomi, pemerintah melakukan berbagai kebijakan-kebijakan. Salah satunya dengan menetapkan Undang-Undang No. 34 Tahun 2000 tentang Perubahan atas Undang-Undang No. 18 Tahun 1997 tentang Pajak Daerah dan Retribusi Daerah. Pemberian kewenangan dalam pengenaan pajak dan retribusi daerah, diharapkan dapat lebih mendorong pemerintah daerah agar terus berupaya untuk mengoptimalkan PAD, khususnya yang berasal dari pajak daerah.

Sebagai daerah tingkat dua, Kota Bandung mempunyai tanggung jawab yang lebih besar dalam mengelola keuangan daerahnya. Hal ini sesuai yang diamanatkan oleh Undang-Undang No. 12 Tahun 2008 tentang Pemerintahan Daerah, bahwa otonomi saat ini lebih ditekankan pada pemerintah daerah tingkat dua (kabupaten/kota). Koswara dalam Halim (2004:35) menyatakan bahwa ciri utama yang menunjukan suatu daerah otonom mampu ber-otonomi terletak pada kemampuan keuangan daerahnya. Artinya bahwa ketergantungan pada bantuan pemerintah pusat harus seminimal mungkin dan PAD harus menjadi bagian sumber keuangan terbesar yang didukung oleh kebijakan keuangan pusat dan daerah.

Keadaan yang terjadi pada pemerintah Kota Bandung diungkap oleh wakil ketua Dewan Perwakilan Daerah (DPD) Iman Gusman (Kompas, 11 Agustus 2006) yang menyebutkan bahwa "otonomi daerah baru menyentuh aspek pemerintahan dan politik, belum menyentuh aspek ekonomi yang merangsang kemandirian daerah". Hal senada diungkapkan oleh Budiyanto dalam 
Halim (2004:139) yang menyebutkan bahwa 'kontribusi PAD terhadap APBD masih relatif kecil atau dengan kata lain, hampir sebagian besar kabupaten/kota belum memiliki tingkat kemandirian'.

Salah satu komponen utama PAD adalah penerimaan dari pajak daerah. Data mengenai kontribusi pajak daerah terhadap PAD di Kota Bandung memperlihatkan bahwa pajak daerah memberikan kontribusi paling besar terhadap PAD Kota Bandung, yaitu rata-rata $61,07 \%$ pertahun. Penerimaan pajak daerah Kota Bandung dari tahun 2002 sampai 2007 terus meningkat. Tetapi peningkatan penerimaan pajak daerah tersebut belum mampu membuat PAD Kota Bandung menjadi sektor penyumbang terbesar dalam pendapatan daerah Kota Bandung.

\begin{tabular}{|c|c|c|c|}
\hline Tahun & PAD - & Jumlah & $\%$ \\
\hline 2001 & 124.021 .491 .559 & 73.583 .061 .441 & 59,33 \\
\hline 2002 & 184.008 .174 .310 & 103.153 .173 .906 & 56,06 \\
\hline 2003 & 217.024 .342 .093 & 117.392 .948 .578 & 54,09 \\
\hline 2004 & 214.831 .096 .006 & 131.803 .120 .422 & 61,35 \\
\hline 2005 & 229.645 .751 .696 & 143.107 .822 .771 & 62,32 \\
\hline 2006 & 253.892 .993 .009 & 164.781 .409 .646 & 64,90 \\
\hline 2007 & 279.503 .175 .471 & 194.128 .259 .768 & 69,45 \\
\hline Rata-ra & & & 61,07 \\
\hline
\end{tabular}

Sumber: Dinas Pendapatan Daerah Kota Bandung (diolah)

Kondisi yang terjadi di Kota Bandung jelas tidak sejalan dengan tujuan otonomi daerah dan hal ini pun terjadi hampir di sebagian besar kabupaten kota di Indonesia. Hal ini menjadi sebuah fenomena tersendiri dalam era otonomi, karena ternyata pemerintah daerah belum mampu melepaskan ketergantungannya terhadap pemerintah pusat. Sesuai dengan hasil penelitian Setiaji dan Adi (2007) yang menyatakan bahwa setelah otonomi, terjadi penurunan peran (share) PAD terhadap total belanja daerah jika dibandingkan dengan era sebelum otonomi yang menyebabkan naiknya tingkat ketergantungan pemerintah daerah terhadap pemerintah pusat.

Salah satu sumber utama penerimaan pajak daerah Kota Bandung adalah pajak penerangan jalan. Pajak penerangan jalan sebelumnya diatur oleh Peraturan Daerah (Perda) Kotamadya Bandung No. 20 Tahun 1998 kemudian diubah dengan Perda Kota Bandung No. 28 Tahun 2002. Dengan dikeluarkan perda tersebut, pajak penerangan jalan mempunyai dasar hukum yang lebih kuat disamping diharapkan penerimaan dari pajak ini semakin meningkat.

Pajak penerangan jalan merupakan salah satu penyumbang terbesar dalam penerimaan pajak daerah Kota Bandung. Dari tahun 2001 sampai 2003 menjadi penyumbang terbesar kedua setelah pajak hotel dan restoran dan dari tahun 2004 sampai 2005 menjadi penyumbang terbesar pajak daerah. Akan tetapi pada tahun 2006 berada pada posisi kedua dan tahun 2007 menjadi penyumbang terbesar ketiga setelah pajak hotel dan pajak restoran (Dipenda Kota Bandung).

Kurang optimalnya pajak daerah di Kota Bandung, terutama pajak penerangan jalan salah satunya disebabkan masih banyaknya tunggakan pajak. Seperti yang dikatakan Kepala Subdinas (Kasubid) Pengendalian Dinas Pendapatan Daerah Kota Bandung Dadang Iriana, bahwa jumlah tunggakan pajak di Kota Bandung hingga akhir Oktober 2007 mencapai Rp.7,4 miliar (Kompas, 30 Oktober 2007). Bahkan pada akhir tahun 2007, menurut keterangan dari Kasubid Dipenda Kota Bandung, jumlah tunggakan pajak meningkat menjadi Rp.10,41 milyar (Okezone.com, 2 November 2007). Pada akhir November 2008, Dipenda Kota Bandung telah menerjunkan 178 penagih pajak untuk mencairkan tunggakan pajak di Kota Bandung. Hal ini dilakukan untuk mencapai target penerimaan pajak daerah sebesar Rp.217 milyar. Menurut Yossi Irianto, pajak yang paling banyak menunggak adalah pajak penerangan jalan, dari target Rp.57,4 miliar baru tercapai sekitar 66,6\% (Pajak.go.id, 27 November 2008). Penyebab utama terjadinya tunggakantungakan pajak penerangan jalan adalah karena banyaknya pelanggan listrik yang menunggak pembayaran listrik.

Pajak penerangan jalan menurut Perda Kota Bandung No. 28 Tahun 2002 tentang merupakan pungutan daerah atas penggunaan tenaga listrik bagi penerangan jalan di daerah. Kota 
Bandung sebagai salah satu kota terbesar di Indonesia dan mempunyai tingkat perekonomian yang tinggi sangat wajar jika jumlah pemakai tenaga listriknya terus meningkat. Oleh karena itu, pemerintah Kota Bandung perlu untuk terus mengoptimalkan pajak penerangan jalan agar dapat memberikan kontribusi yang lebih besar lagi terhadap penerimaan pajak daerah yang nantinya berimbas pada PAD Kota Bandung sendiri. Selain itu, pajak ini termasuk cocok terutama untuk daerah perkotaan (Devas, 1989:66).

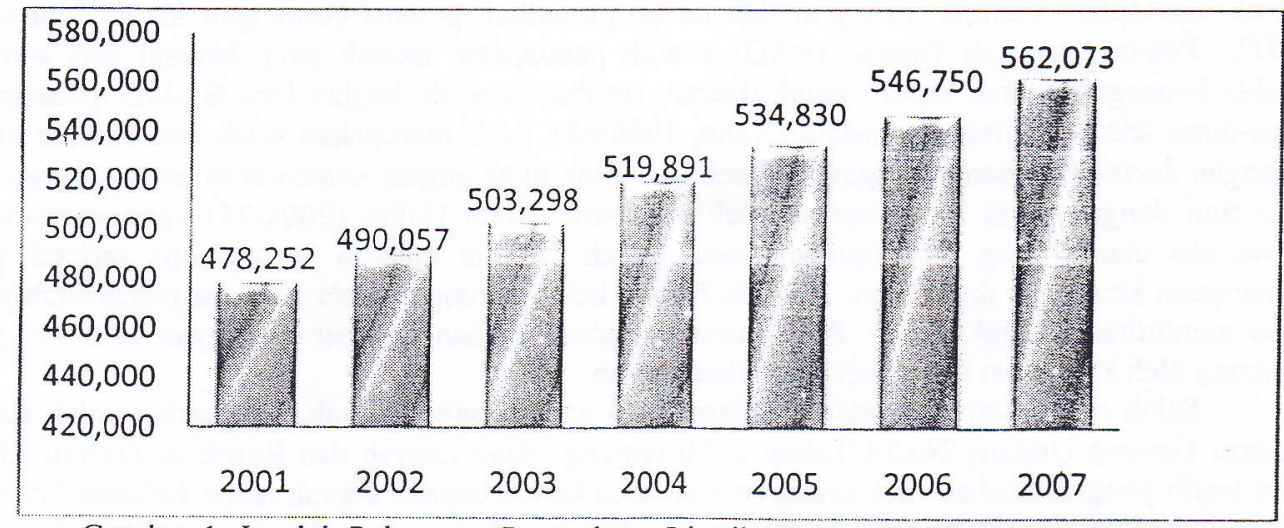

Gambar 1. Jumlah Pelanggan Perusahaan Listrik Negara (PLN) di Kota Bandung (PT.PLN APJ Bandung)

Penelitian sebelumnya yang terkait dengan masalah pajak penerangan jalan adalah penelitian yang dilakukan oleh Virny Kumalasari (2005) dengan hasil: jumlah pelanggan PLN dan penerimaan PLN dari tagihan rekening listrik pelanggan sektor rumah tangga berpengaruh signifikan terhadap penerimaan pajak penerangan jalan kelompok rumah tangga di Kota Surabaya. Serta penelitian Ismartani (2006) dengan hasil: bahwa efisiensi dan efektifitas pajak penerangan jalan di DKI (Daerah Khusus Ibukota) Jakarta cukup baik, tarif dasar listrik dan jumlah pelanggan menunjukan pengaruh yang kuat terhadap penerimaan pajak penerangan jalan di DKI Jakarta serta pertumbuhan ekonomi dan pendapatan perkapita berpengaruh positif terhadap penerimaan pajak penerangan jalan di DKI Jakarta.

\section{Rumusan Masalah}

Begitu luasnya masalah yang berhubungan dengan judul penelitian yang telah dipaparkan pada latar belakang di atas, maka penulis hanya mengidentifikasi masalah yang diteliti sebagai berikut; (1) Bagaimana potensi dari pajak penerangan jalan di Kota Bandung, (2), Bagaimana tingkat efektifitas dari pajak penerangan jalan di Kota Bandung, (3) Bagaimana kontribusi pajak penerangan jalan terhadap pajak daerah dan PAD Kota Bandung, (4) Bagaimana gambaran penerimaan pajak penerangan jalan di Kota Bandung pada tahun-tahun yang akan datang dengan analisis deret waktu.

\section{Kerangka Pemikiran}

Otonomi daerah dilaksanakan secara utuh mulai tahun 2001. Sejak saat itu maka daerah diberi keleluasaan atau kewenangan oleh pemerintah pusat untuk menyelenggarakan pemerintahan dalam segala bidang sesuai dengan undang-undang. Mardiasmo (2002:99) mengatakan bahwa dalam otonomi daerah atau desentralisasi terkandung tiga misi utama, yaitu; (a) Menciptakan efektivitas dan efisiensi pengelolaan sumber daya daerah, (b) Meningkatkan kualitas pelayanan umum dan kesejahteraan masyarakat, (c) Memberdayakan dan menciptakan ruang bagi masyarakat untuk ikut serta (berpartisipasi) dalam proses pembangunan.

Hal yang sama juga diutarakan oleh Wijaya (2002:22) bahwa tujuan yang hendak dicapai dalam penyerahan urusan dari pusat ke daerah (otonomi daerah) antara lain "menumbuhkembangkan daerah berbagai bidang, meningkatkan pelayanan kepada masyarakat, menumbuhkan kemandirian daerah dan meningkatkan daya saing daerah dalam proses pertumbuhan". 
Dalam rangka meningkatkan kemandirian dan kemampuan pelaksanaan otonomi daerah, diperlukan faktor-faktor pendukung, seperti yang dikemukakan Syamsi (1986) dalam Dewi (2002:2), yaitu kemampuan struktural organisasinya, kemampuan aparatur daerah, kemampuan mendorong partisipasi masyarakat dan kemampuan keuangan daerah, diantara faktor-faktor tersebut, faktor keuangan merupakan faktor essensial untuk mengukur tingkat kemampuan daerah dalam melaksanakan otonominya.

Sedangkan Sidik (2002) menyatakan bahwa: "dalam era otonomi daerah, pemerintah daerah diharapkan mampu menggali dan mengoptimalkan potensi (keuangan lokal), khususnya PAD". Pendapatan Asli Daerah (PAD) adalah pendapatan daerah yang berasal dari sumbersumber keuangan daerah seperti pajak daerah, retribusi daerah, bagian laba BUMD, penerimaan dinas-dinas dăn penerimaan lain-lain (Kaho, 1998:68). PAD merupakan salah satu sumber utama keuangan daerah dan banyak digunakan sebagai tolok ukur tingkat kemandirian suatu daerah. Hal ini sesuai dengan yang diungkapkan oleh Koswara dalam Halim (2004:35) yang menyatakan bahwa ciri utama yang menunjukan suatu daerah otonom mampu ber-otonomi terletak pada kemampuan keuangan daerahnya. Artinya bahwa ketergantungan pada bantuan pemerintah pusat harus seminimal mungkin dan PAD harus menjadi bagian sumber keuangan terbesar yang didukung oleh kebijakan keuangan pusat dan daerah

Salah satu komponen utama dalam PAD adalah pajak daerah. Pengertian pajak daerah menurut Undang-Undang No.34 Tahun 2000 tentang Pajak Daerah dan Retribusi Daerah adalah Iuran wajib yang dilakukan oleh orang pribadi atau badan kepada daerah tanpa imbalan langsung yang seimbang, yang dapat dipaksakan berdasarkan peraturan per-undangan yang berlaku, yang digunakan untuk membiayai penyelenggaraan pemerintahan daerah dan pembangunan daerah.

Salah satu jenis dari pajak daerah adalah pajak penerangan jalan. Devas (1989:66) mengatakan bahwa "pajak ini boleh dikatakan cocok untuk sumber penerimaan daerah, terutama untuk daerah berkembang dengan syarat adanya layanan listrik". Pengelolaan pajak ini dilakukan oleh pemerintah daerah melalui Dinas Pendapatan Daerah (Dipenda) dengan bekerja sama dengan PLN.

Pajak penerangan jalan menurut Undang-Undang No.34 Tahun 2000 tentang Pajak Daerah dan Retribusi Daerah adalah "pajak atas penggunaan tenaga listrik, dengan ketentuan bahwa di wilayah daerah tersebut tersedia penerangan jalan, yang rekeningnya dibayar oleh pemerintah daerah". Pajak penerangan jalan bisa terus diupayakan dan dimaksimalkan pemungutannya sesuai dengan peraturan per-undang-undangan yang berlaku. Meningkatkan pajak ini akan secara otomatis meningkatkan pajak daerah dan PAD serta diharapkan akan memperlancar jalannya pembangunan dan pemerintahan. Bila pembangunan bisa berjalan dengan lancar maka kesejahteraan masyarakat juga diharapkan akan meningkat. Dalam rangka otonomi daerah, seperti yang diutarakan Sidik (2002) bahwa pemerintah daerah perlu untuk menggali potensi keuangan lokal, maka perlu adanya penilaian terhadap sumber-sumber PAD khususnya pajak daerah. Sudah jelas bahwa pajak penerangan jalan termasuk dalam komponen pajak daerah dan PAD, maka perlu untuk melakukan penilaian terhadap jenis pajak ini.

Perhitungan potensi dilakukan untuk mengetahui kekuatan yang ada di suatu daerah untuk menghasilkan sejumlah penerimaan dari suatu jenis pajak (Devas, 1989:144 dan Halim, 2004:97). Efektivitas digunakan untuk mengetahui kemampuan daerah dalam merealisasikan penerimaan yang direncanakan dibandingkan dengan target yang ditetapkan berdasarkan potensi riil (Budiyanto dalam Halim, 2004:135). Sedangkan menurut Devas (1989:144), efektivitas digunakan untuk mengetahui hubungan antara hasil pungut suatu pajak dengan potensi pajak itu sendiri. Analisis kontribusi digunakan untuk mengetahui besarnya sumbangan dari suatu pajak terhadap pajak daerah ataupun PAD (Djarwanto, 1993:148-149). Analisis laju pertumbuhan digunakan untuk mengukur tingkat pertumbuhan suatu pajak atau memperoleh gambaran nilai penerimaan dari pajak tersebut (Halim, 2004:163). Selain itu, untuk melihat penerimaan pajak penerangan jalan pada masa yang akan datang, dilakukan analisis menggunakan deret waktu. Analisis ini digunakan dengan maksud untuk memperkirakan sesuatu pada waktu yang akan datang berdasarkan data-data masa lampau yang dianalisisi secara ilmiah, khususnya menggunakan metode statistik (Sudjana, 1991:238).

Oleh karena itu jika pengelolaan pajak daerah, termasuk pajak penerangan jalan sudah baik maka akan berdampak dengan naiknya kontribusi pajak daerah dalam PAD dan akhirnya 
dapat meningkatkan kontribusi PAD terhadap total pendapatan daerah. Seperti yang sudah kita ketahui bahwa salah satu derajat kemandirian daerah adalah besarnya sumbangan PAD dalam total pendapatan daerah (Koswara dalam Halim, 2004:35 dan Sidik, 2002).

\section{Metodologi Penelitian}

Berdasarkan jenis data dalam penelitian ini, maka metode yang digunakan adalah metode penelitian kuantitatif. Sedangkan berdasarkan tujuan dari penelitian ini, yaitu untuk mengetahui gambaran tentang pajak penerangan jalan di Kota Bandung. Maka metode yang diambil adalah metode penelitian berdasarkan tingkat eksplanasinya yaitu metode penelitian deskriptif. Data yang digunakan dalam penelitian ini adalah data sekunder menurut deret waktu (time series). Termasuk kedalam data sekunder karena data merupakan yang telah ada. Data yang akan digunakan dalam penelitian ini adalah; (1) PDRB Kota Bandung (harga konstan dan harga berlaku) tahun 20002007, (2) Laporan realisasi PAD Kota Bandung tahun 2000-2007, (3) Data rinci mengenai pajak penerangan jalan Kota Bandung tahun 2000-2007, (3) Rekapitulasi pembuatan rekening listrik Kota Bandung tahun 2001-2007.

\section{Teknik Analisis Data}

Teknik analisis data yang digunakan dalam penelitian ini guna mencapai tujuan penelitian adalah sebagai berikut:

1) Potensi pajak penerangan jalan

Untuk menghitung potensi $\mathrm{PAD}$ suatu daerah dapat dilakukan secara makro dan mikro (Simanjuntak dalam Halim, 2004:100). Perhitungan Potensi suatu jenis pajak, termasuk ke dalam perhitungan potensi PAD secara mikro. Perhitungan potensi dari penerimaan pajak penerangan jalan di lakukan dengan menggunakan rumus dasar sebagai berikut (Syahputra, 2006:2)

Potensi $=$ tarif pajak $\times$ jumlah objek yang dikenakan pajak

Untuk menghitung potensi pajak penerangan jalan di Kota Bandung dilakukan dengan berpedoman pada Perda Kodya Bandung No.20 Tahun 1998 tentang Pajak Penerangan Jalan dan Peraturan Daerah Kota Bandung No.28 Tahun 2002 tentang Perubahan Atas Perda Kodya Bandung tentang Pajak Penerangan Jalan. Langkah-langkah dalam melakukan perhitungan potensi pajak penerangan jalan Kota Bandung adalah sebagai berikut:

a) Melakukan perhitungan per kelompok dari objek pajak

Tabel 3.2 Perhitungan Potensi Pajak Penerangan Jalan (Perda No.20 Tahun 1998)

\begin{tabular}{|l|l|}
\hline \multicolumn{2}{|c|}{ Tenaga Listrik Yang berasal dari PLN } \\
\hline Golongan & \multicolumn{1}{|c|}{ Formula } \\
\hline Industri & $\begin{array}{l}\text { Rata-rata nilai jual tenaga listrik/bulan } \times 3 \% \times \text { jumlah wajib } \\
\text { pajak } \times 12 \text { bulan }\end{array}$ \\
\hline Bukan Industri & $\begin{array}{l}\text { Rata-rata nilai jual tenaga listrik/bulan } \times 4,5 \% \times \text { jumlah wajib } \\
\text { pajak } \times 12 \text { bulan }\end{array}$ \\
\hline Industri & Tenaga listrik yang bukan berasal dari PLN \\
\hline Bukan Industri & $\begin{array}{l}\text { Rata-rata kapasitas yang tersedia/taksiran penggunaan listrik } \times \\
\text { harga satuan listrik }) \times 9 \% \times \text { jumlah wajib pajak } \times 12 \text { bulan }\end{array}$ \\
\hline $\begin{array}{l}\text { Rata-rata kapasitas yang tersedia/taksiran penggunaan listrik } \times \\
\text { harga satuan listrik) } \times 9 \% \times \text { jumlah wajib pajak } \times 12 \text { bulan }\end{array}$ \\
\hline
\end{tabular}


Tabel 3.3 Perhitungan Potensi Pajak Penerangan Jalan (Perda No.28 Tahun 2002)

\begin{tabular}{|l|l|}
\hline \multicolumn{1}{|c|}{ Genaga Listrik Yang berasal dari PLN } \\
\hline \multicolumn{1}{|c|}{ Golongan } & \multicolumn{1}{c|}{ Formula } \\
\hline Industri (I.1 dan I.2) & $\begin{array}{l}\text { (Rata-rata nilai jual tenaga listrik/bulan } \times 30 \% \times 10 \% \times \text { jumlah } \\
\text { wajib pajak } \times 12 \text { bulan }\end{array}$ \\
\hline Industri (I.3 dan I.4) & $\begin{array}{l}\text { (Rata-rata nilai jual tenaga listrik/bulan } \times 30 \%) \times 8,3 \% \times \\
\text { jumlah wajib pajak } \times 12 \text { bulan }\end{array}$ \\
\hline Bukan Industri & $\begin{array}{l}\text { Rata-rata nilai jual tenaga listrik/bulan } \times 3 \% \times \text { jumlah wajib } \\
\text { pajak } \times 12 \text { bulan }\end{array}$ \\
\hline \multicolumn{2}{|c|}{ Tenaga listrik yang bukan berasal dari PLN } \\
\hline Industri & $\begin{array}{l}\text { (Rata-rata kapasitas yang tersedia/taksiran penggunaan listrik } \times \\
\text { harga satuan listrik) } \times 30 \% \times \text { jumlah objek } \times 9 \% \times 12 \text { bulan }\end{array}$ \\
\hline Bukan Industri & $\begin{array}{l}\text { Rata-rata kapasitas yang tersedia/taksiran penggunaan listrik } \times \\
\text { harga satuan listrik) } \times \text { jumlah objek } \times 9 \% \times 12 \text { bulan }\end{array}$ \\
\hline
\end{tabular}

b) Menjumlahkan semua kelompok tersebut. Jumlah keseluruhan tersebut adalah potensi keseluruhan dari penerimaan pajak penerangan jalan.

2) Efektivitas pajak penerangan jalan

Untuk menghitung efektivitas pajak penerangan jalan pertahun dapat dilakukan dengan membandingkan antara hasil pungutan pajak ponerangan jalan (realisasi) dengan potensi riil dari pajak penerangan jalan (Devas, 1989:144). Rumusnya adalah:

Efektivitas $=\frac{\text { Realisasi Penerimaan Pajak Penerangan Jalan }}{\text { Potensi Pajak Penerangan Jalan }} \times 100 \%$

Untuk menilai efektif tidaknya pemungutan pajak penerangan jalan, maka dapat ditafsirkan pada kriteria yang dikeluarkan oleh Departemen Dalam Negeri (Depdagri), sebagai berikut:

Tabel 3.4 Tabel Interpretasi Nilai Efektivitas

\begin{tabular}{|c|c|}
\hline Persentase & Kriteria \\
\hline$>100 \%$ & Sangat Efektif \\
\hline $90-100 \%$ & Efektif \\
\hline $80-90 \%$ & Cukup Efektif \\
\hline $60-80 \%$ & Kurang Efektif \\
\hline$<60 \%$ & Tidak Efektif \\
\hline
\end{tabular}

Sumber : Depdagri, Kepmendagri No.690.900.327 tahun 1996

3) Kontribusi pajak penerimaan jalan

Untuk mengetahui tesamya kontribusi pajak penerangan jalan terhadap pajak daerah dan Pendapatan Asli Daerah, digunakan metode angka pembanding. Rumusnya (Djarwanto Ps, 1993: 148-149):

Kontribusi $=\frac{\text { Realisasi Penerimaan PPJ }}{\text { Realisasi Penerimaan Pajak Daerah atau PAD }} \times 100 \%$

Untuk menilai tingkat rasio kontribusi pajak penerangan jalan terhadap pajak daerah dan PAD dapat diinterpretasikan pada kriteria yang dikeluarkan oleh tim Litbang Depdagri Fisipol UGM sebagai berikut: 
Tabel 3.6 Interpretasi Nilai Kontribusi

\begin{tabular}{|c|c|}
\hline Persentase & Kriteria \\
\hline Rasio $0,00-10,00 \%$ & Sangat Kurang \\
\hline Rasio $10,00-20,00 \%$ & Kurang \\
\hline Rasio $20,10-30,00 \%$ & Sedang \\
\hline Rasio $30,10-40,00 \%$ & Cukup \\
\hline Rasio $40,10-50,00 \%$ & Baik \\
\hline Rasio diatas $50,00 \%$ & Sangat Baik \\
\hline
\end{tabular}

4) Prospek penerimaan pajak penerangan jalan dimasa yang akan datang

Untuk memperkirakan penerimaan dari pajak penerangan jalan pada waktu yang akan datang, maka digunakan analisis deret waktu (Sudjana, 1991:238). Metode yang akan digunakan adalah metode klasik dengan menggunakan pengaruh trend dan pengaruh gabungan siklusresidu. Cara trend linear yang akan digunakan adalah dengan cara kuadrat terkecil.

\section{Hasil Penelitian}

\section{Potensi Pajak Penerangan Jalan}

Berdasarkan perhitungan potensi pajak penerangan jalan di Kota Bandung, dapat diketahui bahwa potensi penerimaan pajak penerangan jalan di Kota Bandung masih perlu untuk terus dioptimalkan. Selain itu, harus ada pendataan resmi mengenai ada tidaknya wajib pajak penerangan jalan yang berasal dari listrik non PLN.

Tabel 4.15 Perkembangan Potensi Pajak Penerangan Jalan Kota Bandung Tahun 2001-2007

\begin{tabular}{|c|c|r|}
\hline Tahiın & Potensi Pajak Penerangan Jalan & Perkembangan \\
\hline 2001 & 28.433 .032 .300 & \\
\hline 2002 & 43.085 .365 .154 & 14.652 .332 .854 \\
\hline 2003 & 37.618 .945 .696 & -5.466 .419 .458 \\
\hline 2004 & 38.649 .536 .255 & 1.030 .590 .559 \\
\hline 2005 & 42.817 .428 .809 & 4.167 .892 .553 \\
\hline 2006 & 44.687 .242 .254 & 1.869 .813 .445 \\
\hline 2007 & 46.378 .480 .076 & 1.691 .237 .822 \\
\hline
\end{tabular}

Sumber : PT.PLN APJ Bandung (diolah)

Berdasarkan tabel 4.15, dapat disimpulkan bahwa sejak tahun 2001 sampai 2007, potensi pajak penerangan jalan di Kota Bandung jumlahnya bervariasi dan jika dilihat secara umum berada pada trend meningkat kecuali untuk tahun 2003 dikarenakan adanya peningkatan yang sangat besar pada tahun 2002. Selain itu jika dilihat kembali dalam hal peningkatan penambahannya terjadi fluktuasi pertumbuhan bahkan terjadi penurunan. Selain itu, berdasarkan uraian diatas, dapat disimpulkan bahwa tarif pajak, tarif dasar listrik, jumlah wajib pajak serta kondisi ekonomi mempunyai pengaruh yang kuat terhadap peningkatan pajak penerangan jalan Kota Bandung. Selain itu, seperti yang diutarakan Devas (1989:144) yang menyebutkan bahwa pajak penerangan jalan cocok untuk daerah perkotaan, menjadikan hal penting bagi Pemerintah Kota Bandung terutama Dipenda dan PT.PLN APJ Bandung untuk terus bekerjasama dalam mengelola pajak penerangan jalan.

\section{Efektivitas Pajak Penerangan Jalan}

Analisis terhadap efektivitas pemungutan pajak penerangan jalan di Kota Bandung dimaksudkan untuk mengetahui sejauh mana kinerja dari Dipenda dan PT. PLN APJ Bandung dalam mengelola pajak ini atau dengan kata lain sejauh mana penerimaan yang berhasil dikumpulkan oleh Kota Bandung dari pajak penerangan jalan jika dibandingkan dengan potensi riil dari pajak tersebut. Semakin efektif pemungutan suatu pajak maka akan semakin besar jumlah penerimaannya. Dalam menilai efektif tidaknya pemungutan pajak penerangan jalan akan mengacu pada kriteria Kepmendagri No.690.900.327 tahun 1996.

Tabel 4.16 Efektivitas Pajak Penerangan Jalan di Kota Bandung Tahun 2001-2007 


\begin{tabular}{|c|c|c|c|c|}
\hline Tahun & $\begin{array}{c}\text { Potensi } \\
(\mathrm{Rp})\end{array}$ & $\begin{array}{c}\text { Realisasi } \\
(\mathrm{Rp})\end{array}$ & $\begin{array}{c}\text { Efektivitas } \\
(\%)\end{array}$ & Kriteria \\
\hline 2001 & 28.433 .032 .300 & 15.060 .034 .201 & 52,97 & Tidak efektif \\
\hline 2002 & 43.085 .365 .154 & 25.356 .011 .581 & 58,85 & Tidak efektif \\
\hline 2003 & 37.618 .945 .696 & 32.525 .723 .305 & 86,46 & Cukup efektif \\
\hline 2004 & 38.649 .536 .255 & 37.942 .246 .124 & 98,17 & Efektif \\
\hline 2005 & 42.817 .428 .809 & 41.215 .767 .653 & 96,26 & Efektif \\
\hline 2006 & 44.687 .242 .254 & 42.937 .686 .526 & 96,08 & Efektif \\
\hline 2007 & 46.378 .480 .076 & 43.349 .978 .810 & 93,47 & Efektif \\
\hline \multicolumn{3}{|c|}{ rata } & 83,18 & Cukup efektif \\
\hline
\end{tabular}

Sumber : PLN APJ Bandung dan Dipenda Kota Bandung (diolah)

Berdasarkan tabel 4.16 tersebut, dapat diketahui bahwa sejak otonomi daerah tahun 2001 sampai 2007 ternyata realisasi penerimaan pajak penerangan jalan selalu berada di bawah potensi riil nya. Akibatnya secara rata-rata efektivitas pajak penerangan jalan dari tahun 2001 sampai 2007 adalah $83,18 \%$ dan dengan mengacu pada kriteria Kepmendagri No.690.900.327 (1996) maka pemungutan pajak penerangan jalan di Kota Bandung termasuk dalam kategori cukup efektif $(80 \%-90 \%)$.

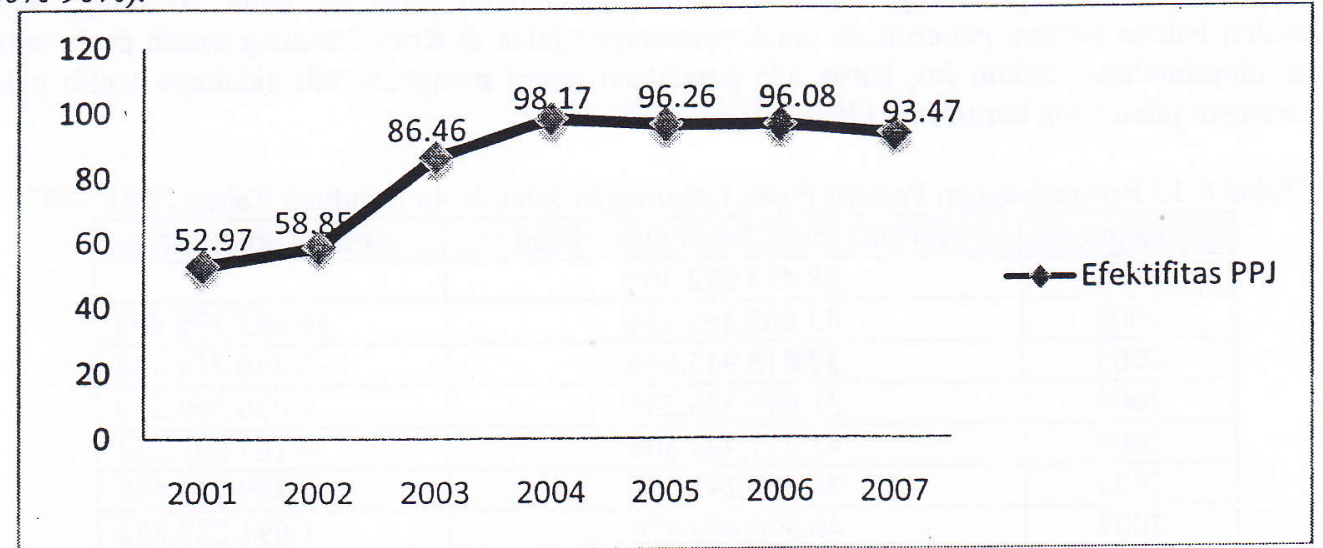

Sumber : Dipenda Kota Bandung Dan PT.PLN APJ Bandung

Gambar 4.7 Laju Efektivitas Pajak Penerangan Jalan Kota Bandung Tahun 2001-2007

Berdasarkan gambar 4.7, dapat dilihat bahwa trend efektivitas pajak penerangan jalan sejak berlakunya otonomi daerah sampai tahun 2007 menunjukan nilai yang bervariasi. Terus naik hingga tahun 2004, kemudian perlahan turun pada tahun 2005, kemudian kembali turun pada tahun 2006 dan tahun 2007. Secara keseluruhan, jika dirata-ratakan nilai efektivitas pemungutan pajak penerangan jalan termasuk dalam kategori cukup efektif karena berada diantara $80 \%-90 \%$, tepatnya $83,18 \%$.

Ada beberapa hal yang menyebabkan rata-rata efektivitas pajak penerangan jalan di Kota Bandung temasuk kategori cukup efektif dan hal-hal yang perlu dilakukan oleh pihak terkait. Pertama, pajak ini seperti yang diungkapkan oleh Bapak Subardan (Divisi Niaga PLN Kota Bandung) kolektibilitas sangat tergantung pada pembayaran rekening listrik, artinya jika banyak pelanggan PLN yang tidak atau menunggak membayar tagihan listriknya maka secara otomatis mereka tidak pula membayar pajak penerangan jalan. Sedangkan untuk Kota Bandung masih banyak tagihan rekening listrik yang tidak tertagih oleh PLN. Oleh karena itu, perlu adanya tindakan yang lebih aktif dari Dipenda Kota Bandung, misalnya dengan bekerjasama dengan pihak PLN Kota Bandung untuk memungut pajak terutang dari pelanggan yang belum membayar tagihan listrik maupun pajak penerangan jalan. Walaupun sebenarnya wewenang untuk melakukan hal tersebut dimiliki oleh PLN, hal tersebut tercantum dalam peraturan perundang-undangan.

Kedua, kebijakan dengan menggunakan target sebagai ukuran keberhasilan pemungutan pajak. Bahkan LPEM-UI dan Clear Urban Project mengatakan bahwa penggunaan sistem target ini 
merupakan salah satu permasalahan dalam peningkatan pendapatan daerah (Sidik, 2002:7). Apalagi ternyata target yang ditetapkan oleh Pemkot Bandung bersama DPRD tidak mengacu pada potensi sebenarnya, melainkan perkiraan berdasarkan perolehan tahun sebelumnya (Bapak Zain Iskandar, Dipenda Bandung). Kurang tepatnya target dijadikan ukuran terlihat dari uraian diatas bahwa walaupun secara umum target penerimaan tercapai tapi belum dapat mencapai potensi sebenarnya dari pajak tersebut. Hal tersebut sesuai dengan yang disebutkan oleh Devas (1989:144) bahwa "ukuran efektivitas adalah potensi dengan anggapan semua wajib pajak membayar pajak terutangnya".

Ketiga, Dipenda sebaiknya mulai melakukan pendataan mengenai ada tidaknya penggunaan listrik diluar yang berasal dari PLN yang memenuhi kriteria wajib pajak dalam Undang-Undang maupun Peraturan Daerah. Hal ini, selain untuk meningkatkan penerimaan daerah juga untuk mencgakkan salah satu syarat dalam pemungutan pajak yaitu asas keadilan (Musgrave dalam Sidik: 2004:132) serta prinsip umum perpajakan daerah yaitu adil dan merata (Sidik, 2002:2-3).

Tabel 4.17 Selisih Potensi dan Realisasi Pajak Penerangan Jalan Kota Bandung Tahun 2001-2007

\begin{tabular}{|c|c|c|r|}
\hline Tahun & Potensi & Realisasi & \multicolumn{1}{|c|}{ Selisih } \\
\hline 2001 & 28.433 .032 .300 & 15.060 .034 .201 & 13.372 .998 .099 \\
\hline 2002 & 43.085 .365 .154 & 25.356 .011 .581 & 17.729 .353 .573 \\
\hline 2003 & 37.618 .945 .696 & 32.525 .723 .305 & 5.093 .222 .391 \\
\hline 2004 & 38.649 .536 .255 & 37.942 .246 .124 & 707.290 .131 \\
\hline 2005 & 42.817 .428 .809 & 41.215 .767 .653 & 1.601 .661 .156 \\
\hline 2006 & 44.687 .242 .254 & 42.937 .686 .526 & 1.749 .555 .728 \\
\hline 2007 & 46.378 .480 .076 & 43.349 .978 .810 & 3.028 .501 .266 \\
\hline \multicolumn{3}{|c|}{ Jumlah } & 43.282 .582 .344 \\
\hline
\end{tabular}

Sumber : Dipenda dan PLN Kota Bandung (diolah)

Berdasarkan tabel 4.17 tersebut, terlihat bahwa selama tahun 2001 sampai 2007 dengan anggapan semua wajib pajak penerangan jalan membayar pajak terutangnya, maka pihak Pemerintah Kota Bandung telah kehilangan potensi pemasukan Rp.43.282.582.344, jumlah yang cukup besar. Apalagi bahwa dalam otonomi daerah, setiap daerah dituntut untuk meningkatkan PAD-nya. Salah satu cara untuk meningkatkan PAD adalah dengan mengoptimalkan pendapatan dari sektor pajak (Sidik, 2002).

Oleh karena itu, pemerintah Kota Bandung sudah seharusnya untuk meningkatkan kinerja pemungutan pendapatan daerah terutama pajak daerah. Karena pajak daerah merupakan komponen utama PAD. Salah satu cara untuk meningkatkan penerimaan pajak daerah dapat dilakukan dengan meningkatkan penerimaan perjenis pajak, diantaranya pajak penerangan jalan. Saat ini, pengelolaan pajak penerangan jalan sudah cukup baik, tinggal memperbaiki beberapa yang masih kurang, diantaranya, proses perhitungan potensi serta penyelarasan antara target yang menjadi tolok ukur dengan potensi riil.

Hal lain yang periu diperhatikan adalah tingkat efektivitas pemunguitan pajak penerangan jalan yang perlu untuk terus ditingkatkan, karena sejak tahun 2005 sampai 2007 terjadi penurunan efektivitas yang berakibat menurunnya posisi pajak ini sebagai penyumbang terbesar bagi penerimaan sektor pajak. Padalah efektivitas pemungutan pajak merupakan faktor utama dalam pengoptimalan penerimaan pajak sesuai dengan penelitian yang dilakukan oleh Ismartani (2006).

Kontribusi Pajak Penerangan Jalan

Berdasarkan tabel 4.21 tersebut, dapat diketahui bahwa setelah efektifnya otonomi daerah sampai dengan tahun 2007 , kontribusi pajak penerangan jalan terhadap pajak daerah nilainya bervariasi. Jika dirata-ratakan dari tahun 2001 sampai 2007, kontribusi pajak penerangan jalan terhadap pajak daerah adalah 25,53 dan dengan mengacu pada kriteria Litbang Depdagri Fisipol UGM (1991) maka kontribusi pajak penerangan jalan di Kota Bandung termasuk dalam kategori sedang. 
Tabel 4.21 Kontribusi Pajak Penerangan Jalan Terhadap Pajak Daerah Tahun 2001 - 2007

\begin{tabular}{|c|c|c|}
\hline Tahun & Kontribusi (\%) & Kriteria \\
\hline 2001 & 20,47 & Sedang \\
\hline 2002 & 24,58 & Sedang \\
\hline 2003 & 27,71 & Sedang \\
\hline 2004 & 28,79 & Sedang \\
\hline 2005 & 28,80 & Sedang \\
\hline 2006 & 26,06 & Sedang \\
\hline 2007 & 22,33 & Sedang \\
\hline Rata-rata & 25,53 & Sedang \\
\hline
\end{tabular}

Sumber : Dipenda Kota Bandung (diolah)

Berdasarkan tabel dan gambar diatas, dapat ditarik kesimpulan bahwa naik turunnya tingkat kontribusi pajak penerangan jalan terhadap pajak daerah disebabkan oleh faktor-faktor berikut, diantaranya tingkat efektivitas pemungutannya, tingkat kenaikan jumlah wajib pajaknya, perubahan peraturan baik berupa perda pajak tersebut maupun perubahan tarif dasar listrik serta besarnya kontribusi jenis pajak daerah lainnya. Hal tersebut memperkuat hasil penelitian yang dilakukan Ismartani (2006) yang menyebutkan bahwa faktor tarif dasar listrik dan jumlah pelanggan PLN berpengaruh kuat terhadap peningkatan penerimaan pajak penerangan jalan. Data mengenai tingkat kontribusi masing-masing jenis pajak daerah terhadap total penerimaan pajak daerah dapat dilihat dalam tabel.4.22.

Tabel 4.22 Kontribusi Masing-Masing Jenis Pajak Daerah Terhadap Penerimaan Pajak Daerah Kota Bandung Tahun 2001-2007

\begin{tabular}{|c|c|c|c|c|c|c|c|}
\hline Jenis Pajak & $a_{2}=2001$ & 2002 & 2003 & 2004 & 2005 & 2006 & .2007 \\
\hline P. Hotel & \multirow{2}{*}{$\begin{array}{c}46.029 .324 .706 \\
(62,55)\end{array}$} & \multirow{2}{*}{$\begin{array}{c}56.434 .696 .206 \\
(54.71)\end{array}$} & \multirow{2}{*}{$\begin{array}{c}62.439 .288 .396 \\
(53,19 \%)\end{array}$} & $\begin{array}{c}35.663 .218 .724 \\
(27.058)\end{array}$ & $\begin{array}{c}39.204 .993 .647 \\
(27,40 \%)\end{array}$ & $\begin{array}{c}44.521 .528 .069 \\
(27,02 \%)\end{array}$ & $\begin{array}{c}58.706 .270 .014 \\
(30.24) \\
\end{array}$ \\
\hline P. Restoran & & & & $\begin{array}{c}30.741 .746 .430 \\
(23.324)\end{array}$ & $\begin{array}{c}33.964 .904 .694 \\
(23,73 \%)\end{array}$ & $\begin{array}{c}35.957 .305 .884 \\
(21,82 \%)\end{array}$ & $\begin{array}{c}48.481 .745 .327 \\
(24.97) \\
\end{array}$ \\
\hline P. Hiburan & $\begin{array}{c}6.335 .449 \text { in } \\
(8,61)\end{array}$ & $\begin{array}{c}5.522 .676 .131 \\
(9.23)\end{array}$ & $\begin{array}{c}9.945 .099 .294 \\
(8,47 \%)\end{array}$ & $\begin{array}{c}10.066 .860 .422 \\
(7.638 \%)\end{array}$ & $\begin{array}{c}10.537 .384 .530 \\
(7.36 \%)\end{array}$ & $\begin{array}{c}11.477 .229 .807 \\
(6,97 \%)\end{array}$ & $\begin{array}{c}15.791 .180 .072 \\
(8.13)\end{array}$ \\
\hline P. Reklame & $\begin{array}{c}3.600 .800 .167 \\
(4,89)\end{array}$ & $\begin{array}{c}7.901 .111 .759 \\
(7.66)\end{array}$ & $\begin{array}{c}10.302 .704 .425 \\
(8,78 \%)\end{array}$ & $\begin{array}{c}14.537 .650 .645 \\
(11,030 \%)\end{array}$ & $\begin{array}{c}14.841 .995 .565 \\
(10,37 \%)\end{array}$ & $\begin{array}{c}26.103 .431 .700 \\
(15,84 \%) \\
\end{array}$ & $\begin{array}{c}23.444 .954 .435 \\
(12.08)\end{array}$ \\
\hline P. Pen Jalan & $\begin{array}{c}15.060 .034 .201 \\
(20,47)\end{array}$ & $\begin{array}{c}25.356 .011 .581 \\
(24.58)\end{array}$ & $\begin{array}{c}32.525 .723 .305 \\
(27,71 \%)\end{array}$ & $\begin{array}{c}37.942 .246 .124 \\
(28,787 \%)\end{array}$ & $\begin{array}{c}41.215 .767 .653 \\
(28,80 \%)\end{array}$ & $\begin{array}{c}42.937 .686 .526 \\
(26,06 \%)\end{array}$ & $\begin{array}{c}43.349 .978 .810 \\
(22.33)\end{array}$ \\
\hline $\begin{array}{l}\text { P. ABT dan } \\
\text { AP }\end{array}$ & $\begin{array}{c}2.454 .757 .553 \\
(3,34) \\
\end{array}$ & $\begin{array}{c}1.444 .481 .310 \\
(1.40)\end{array}$ & $\begin{array}{c}63.218 .950 \\
(0,05 \%)\end{array}$ & - & - & - & 年 \\
\hline Pajak Parkir & $\begin{array}{c}100.767 .020 \\
(0,14)\end{array}$ & $\begin{array}{c}2.494 .196 .919 \\
(2.42)\end{array}$ & $\begin{array}{c}2.116 .914 .208 \\
(1,80 \%)\end{array}$ & $\begin{array}{c}2.848 .481 .627 \\
(2,161 \%) \\
\end{array}$ & $\begin{array}{c}3.285 .018 .410 \\
(2,30 \%)\end{array}$ & $\begin{array}{c}3.668 .523 .042 \\
(2,23 \%)\end{array}$ & $\begin{array}{c}4.267 .541 .604 \\
(2.20) \\
\end{array}$ \\
\hline $\begin{array}{l}\text { P.Rumah } \\
\text { Kos }\end{array}$ & - & $x-7$ & - & $\begin{array}{l}2.916 .450 \\
(0,002 \%) \\
\end{array}$ & $\begin{array}{c}57.756 .272 \\
(0,04 \%)\end{array}$ & $\begin{array}{c}115.704 .618 \\
(0,07 \%)\end{array}$ & $\begin{array}{c}86.589 .506 \\
(0.04)\end{array}$ \\
\hline Total & 73.583 .061 .441 & 103.153 .173 .906 & 117.392 .948 .578 & 131.803 .120 .422 & 143.107 .820 .771 & 164.781 .409 .646 & 194.128 .259 .768 \\
\hline
\end{tabular}

Sumber : Dinas Pendapatan Daerah Kota Bandung (diolah)

Tabel 4.23 Kontribusi Masing-Masing Komponen PAD Terhadap PAD

Kota Bandung Tahun 2001-2007

\begin{tabular}{|c|c|c|c|c|c|c|c|}
\hline & & & \\
\hline Uraian & 2001 & 2002 & 2003 & 2004 & 2005 & 2006 & 2007 \\
\hline $\begin{array}{l}\text { Pajak } \\
\text { Daerah }\end{array}$ & $\begin{array}{c}73.538 .06 ! 44 ! \\
(59.29)\end{array}$ & $\begin{array}{c}103.153 .173 .907 \\
(56,06)\end{array}$ & $\begin{array}{c}117.392 .948 .578 \\
(54.09)\end{array}$ & $\begin{array}{c}131.803 .120 .422 \\
(61,35)\end{array}$ & $\begin{array}{c}143.107 .822 .771 \\
(62,32)\end{array}$ & $\begin{array}{c}164.781 .409 .646 \\
(64,90)\end{array}$ & $\begin{array}{c}194.128 .259 .768 \\
(69,45)\end{array}$ \\
\hline $\begin{array}{l}\text { Retribusi } \\
\text { Daerah } \\
\end{array}$ & $\begin{array}{c}35.294 .779 .192 \\
(28.46)\end{array}$ & $\begin{array}{c}48.760 .223 .797 \\
(26.50)\end{array}$ & $\begin{array}{c}54.465 .407 .287 \\
(25.10)\end{array}$ & $\begin{array}{c}62.655 .014 .052 \\
(29,16)\end{array}$ & $\begin{array}{c}65.873 .568 .195 \\
(28,68)\end{array}$ & $\begin{array}{c}75.908 .865 .024 \\
(29,90)\end{array}$ & $\begin{array}{c}66.150 .795 .925 \\
(23,67)\end{array}$ \\
\hline $\begin{array}{l}\text { Bag. Laba } \\
\text { BUMD }\end{array}$ & $\begin{array}{c}1.501 .769 .951 \\
(1,21)\end{array}$ & $\begin{array}{c}2.236 .810 .668 \\
(1.22)\end{array}$ & $(2,10)+1$ & $(2,, 10)$ & $\begin{array}{c}2.552 .953 .482 \\
(1,11)\end{array}$ & $\begin{array}{c}3.155 .367 .154 \\
(1,24)\end{array}$ & $\begin{array}{c}3.763 .740 .190 \\
(1,35)\end{array}$ \\
\hline $\begin{array}{l}\text { Lain-Lain } \\
\text { PAD }\end{array}$ & $\begin{array}{c}13.686 .880 .975 \\
(11,04)\end{array}$ & $\begin{array}{c}29.857 .965 .938 \\
(16.23)\end{array}$ & \begin{tabular}{|c|}
45.165 .986 .228 \\
$(20.81)$
\end{tabular} & $\begin{array}{c}20.372 .961 .532 \\
(9,48)\end{array}$ & $\begin{array}{c}18.111 .407 .248 \\
(7,89)\end{array}$ & $\begin{array}{c}10.047 .351 .185 \\
(3,96)\end{array}$ & $\begin{array}{c}15.460 .379 .588 \\
(5,53)\end{array}$ \\
\hline & 124.021 .491 .559 & 184.008 .174 .310 & 217.024 .342 .093 & 214.831 .096 .006 & 229.645 .751 .696 & 253.892 .993 .009 & 279.503 .175 .471 \\
\hline
\end{tabular}

Pajak daerah merupakan komponen utama dalam PAD. Untuk Kota Bandung sendiri, kontribusi pajak daerah sangatlah besar seperti yang terlihat dalam tabel 4.23. Dalam tabel tersebut 
dapat diketahui bahwa pos pajak daerah menyumbangkan rata-rata $61,07 \%$ pertahun selama tahun 2001 sampai 2007. Sedangkan pos lainnya yaitu retribusi, bagian laba BUMD dan lain-lain PAD yang sah berturut-turut menyumbangkan rata-rata $23,35 \%, 0,88 \%$ dan $10,7 \%$ pertahun. Tahun 2007 merupakan tahun di mana pajak daerah menyumbangkan 69,45\% untuk PAD dan merupakan sumbangan terbesar selama era otonomi.

Pajak penerangan Jalan merupakan komponen dari pajak daerah dan pajak daerah merupakan komponen utama atau penyumbang terbesar PAD Kota Bandung seperti yang terlihat dalam tabel 4.23. Kontribusi Pajak Penerangan Jalan terhadap PAD dari tahun 2001 sampai 2007 berada pada rata-rata $15,56 \%$ (tabel 4.24) dan jika merujuk pada kriteria yang dikeluarkan oleh Tim Litbang Depdagri Fisipol UGM (1991) termasuk dalam kategori kurang. Tapi perlu diingat disini karena lingkup pajak penerangan jalan secara langsung masuk terlebih dahulu kepada pos pajak daerah.

Tabel 4.24 Kontribusi Pajak Penerangan Jalan Terhadap PAD

Kota Bandung Tahun 2001-2007

\begin{tabular}{|c|c|c|c|c|}
\hline Tahun & $\begin{array}{c}\text { Pajak Penerangan } \\
\text { Jalan (Rp) }\end{array}$ & $\begin{array}{c}\text { PAD } \\
(\mathrm{Rp})\end{array}$ & $\begin{array}{c}\text { Kontribusi } \\
(\%)\end{array}$ & Kriteria \\
\hline 2001 & 15.060 .034 .201 & 124.021 .491 .559 & 12,14 & Kurang \\
\hline 2002 & 25.356 .011 .581 & 184.008 .174 .310 & 13,78 & Kurang \\
\hline 2003 & 32.525 .723 .305 & 217.024 .342 .093 & 14,99 & Kurang \\
\hline 2004 & 37.942 .246 .124 & 214.831 .096 .006 & 17,66 & Kurang \\
\hline 2005 & 41.215 .767 .653 & 229.645 .751 .696 & 17,95 & Kurang \\
\hline 2006 & 42.937 .686 .526 & 253.892 .993 .009 & 16,91 & Kurang \\
\hline 2007 & 43.349 .978 .810 & 279.503 .175 .471 & 15,51 & Kurang \\
\hline \multicolumn{5}{|c|}{ Rata-rata } \\
\hline
\end{tabular}

Sumber : Dinas Pendapatan Daerah Kota Bandung (diolah)

Secara umum, faktor-faktor yang mempengaruhi naik turunnya kontribusi pajak penerangan jalan terhadap PAD sama dengan faktor-faktor pada pajak daerah. Diantaranya tingkat efektivitas pemungutan pajaknya, perkembangan jumlah wajib pajaknya, kebijakan-kebijakan yang dikeluarkan oleh pemerintah atau pihak lain yang berhubungan dengan pajak penerangan jalan serta tingkat perkembangan dari sektor lain yang ada dalam PAD.

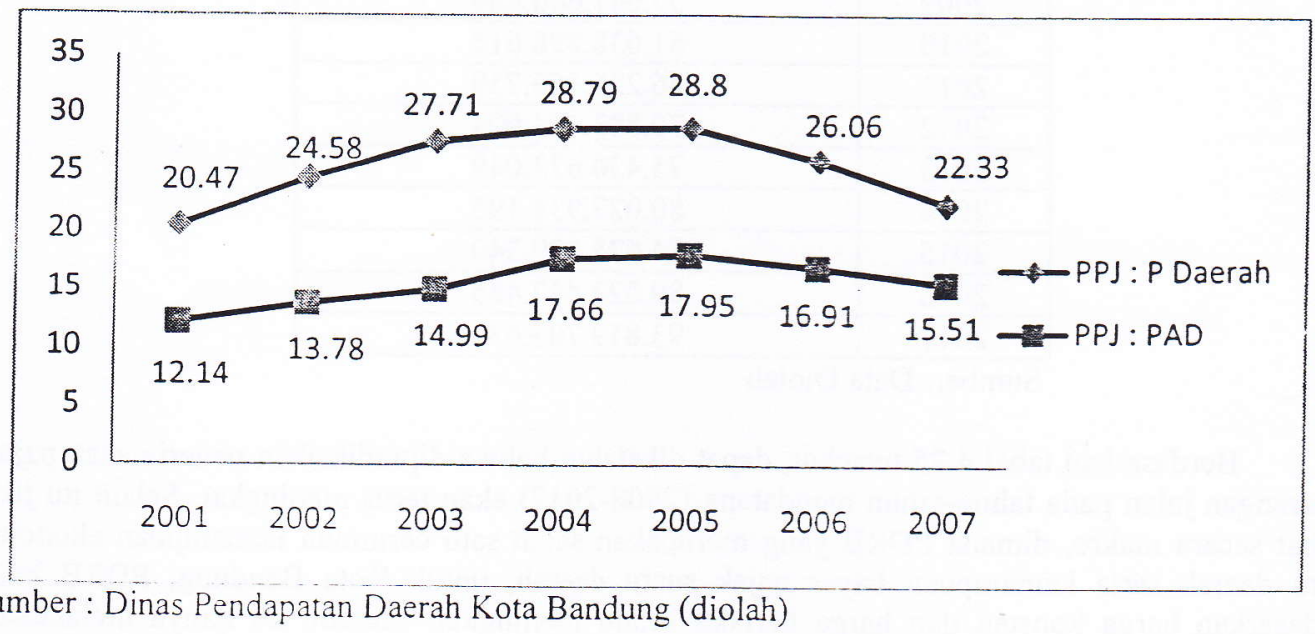

Gambar 4.12 Perbandingan Kontribusi Pajak Penerangan Jalan terhadap Pajak Daerah dan PAD Tahun 2001-2007

Berdasarkan tabel 4.24 dan gambar 4.12 diatas, kontribusi pajak penerangan jalan terhadap PAD secara umum polanya tidak jauh berbeda dengan pola kontribusi pajak ini terhadap pajak daerah. Hal ini terlihat dari gerak kontribusi yang terus meningkat dari tahun 2001 sampai 
2005 dan kemudian bergerak turun mulai tahun 2006. Angka kontribusi tertinggi yang diberikan pajak ini terhadap PAD adalah 17,95\% yang terjadi pada tahun 2005 di mana pada tahun tersebut kontribusi pajak penerangan terhadap pajak daerah pun berada pada titik tertinggi yaitu $28,8 \%$. Berarti dapat disimpulkan bahwa semakin tinggi tingkat kontribusi pajak penerangan jalan terhadap pajak daerah, semakin tinggi pula kontribusi pajak ini terhadap PAD Kota Bandung.

Sebagai salah satu sumber utama pajak daerah dan juga PAD, kondisi yang terjadi pada pajak penerangan jalan ini yang kontribusinya sejak tahun 2006 berada pada trend menurun padahal sejak tahun 2001 sampai tahun 2005 terus bergerak naik perlu dilakukan perbaikan terutama oleh pihak yang mempunyai tugas dan tanggung jawab terhadap hal ini. Hal ini perlu dilakukan supaya kontribusi pajak penerangan jalan kembali meningkat, yang pada akhirnya dapat meningkatkan PAD Kota Bandung itu sendiri. Karena dalam era otonomi daerah, tingkat kemandirian daerah harus meningkat. Selain itu, salah satu ukuran keberhasilan otonomi adalah kemampuan keuangan daerah (Syamsi, 1986 dan Kaho, 1998).

Salah satu faktor utama yang berpengaruh terhadap tingkat kontribusi pajak penerangan jalan terhadap pajak daerah ataupun PAD di Kota Bandung adalah tingkat efektifita spemungutan pajak ini, semakin tinggi tingkat efektiñtasnya semakin tinggi pula tingkat kontribusinya. Hal ini terlihat dari data, bahwa pada tahun 2004 dan 2005, pajak penerangan jalan merupakan penyumbang terbesar untuk penerimaan pajak daerah $(28,78 \%$ dan $28,80 \%)$ dan pada tahun tersebut tingkat efektivitas dari pemungutan pajak juga merupakan yang tertinggi. Jadi dengan berkurangnya efektivitas pemungutan pajak penerangan jalan pada tahun 2006 dan 2007 jelas merupakan sesuatu yang kurang baik.

\section{Perkiraan Penerimaan Pajak Penerangan Jalan Tahun-Tahun Mendatang}

Perhitungan penerimaan pajak penerangan jalan tahun-tahun mendatang dimaksudkan untuk mengetahui bagaimana penerimaan pajak ini, apakah terus meningkat atau justru menurun dalam bentuk kuantitatif, walaupun dalam perkiraan ini hanya memperkirakan secara kasar (gambaran umum), hanya pengaruh trend dan pengaruh gabungan siklus-residu tanpa memperhitungkan faktor-faktor yang berpengaruh lainnya.

Tabel 4.25 Perkiraan Penerimaan Pajak Penerangan Jalan Kota Bandung Tahun 2008-2017

\begin{tabular}{|c|c|}
\hline Tahun & $\begin{array}{c}\text { Proyeksi Penerimaan } \\
\text { Pajak Penerangan Jalan }\end{array}$ \\
\hline 2008 & 52.444 .382 .324 \\
\hline 2009 & 57.041 .640 .469 \\
\hline 2010 & 61.638 .898 .614 \\
\hline 2011 & 66.236 .156 .759 \\
\hline 2012 & 70.833 .414 .904 \\
\hline 2013 & 75.430 .673 .049 \\
\hline 2014 & 80.027 .931 .195 \\
\hline 2015 & 84.625 .189 .340 \\
\hline 2016 & 89.222 .447 .485 \\
\hline 2017 & 93.819 .705 .630 \\
\hline
\end{tabular}

Sumber: Data Diolah

Berdasarkan tabel 4.25 tersebut, dapat diketahui bahwa diprediksikan penerimaaan pajak penerangan jalan pada tahun-tahun mendatang (2008-2017) akan terus meningkat. Selain itu jika dilihat secara makro, dimana PDRB yang merupakan salah satu cerminan kemampuan ekonomi suatu daerah serta kemampuan bayar pajak suatu daerah, untuk Kota Bandung, PDRB baik berdasarkan harga konstan dan harga berlaku selalu meningkat. Metode ini hanya melakukan perkiraan secara kasar, dan hanya memperhitungkan faktor trend dan gabungan silkus-residu. Untuk melakukan perkiraan atau proyeksi yang lebih mendekati sebenarnya perlu melibatkan banyak faktor. Walaupun demikian, perkiraan dengan metode ini dalam beberapa keadaan sudah cukup menggambarkan (Sudjana, 1991:240). Selain itu, jika perhitungan potensi riil (yang memang rumit dan perlu banyak informasi), metode ini dapat dijadikan metode altematif yang mungkin dapat dipakai pemerintah daerah Kota Bandung dalam menentukan target penerimaan 

pajak penerangan jalan walaupun akan lebih baik dengan menghitung potensi suatu pajak secara
rill.

\section{Simpulan}

Bedasarkan hasil dari analisis dan uraian pada bab-bab sebelumnya mengenai pajak penerangan jalan di Kota Bandung, maka dapat diambil kesimpulan sebagai berikut :

1) Potensi pajak penerangan jalan Kota Bandung setelah berlakunya otonomi daerah sampai tahun 2007 secara umum terus menunjukan peningkatan dengan tingkat pertumbuhan yang berbeda, kecuali untuk tahun 2003 yang mengalami pertumbuhan negatif.

2) Efektivitas pemungutan pajak penerangan jalan Kota Bandung dari tahun 2001 sampai 2007 nilainya bervariasi dengan rata-rata $83,18 \%$ dan termasuk kriteria cukup efektif. Nilai efektivitas tertinggi terjadi pada tahun 2004 yaitu $98,17 \%$ (efektif) sedangkan terendah terjadi pada tahun 2001 sebesar $52,97 \%$ (tidak efektif). Secara umum, efektivitas pajak penerangan jalan berada pada trend naik sampai tahun 2004 dan menurun mulai tahun 2005.

3) Kontribusi pajak penerangan jalan terhadap pajak daerah selama tahun 2001 sampai 2007 mempunyai rata-rata $25,53 \%$ dan termasuk kategori sedang. Kontribusi tertinggi terjadi tahun 2005 yaitu $28,8 \%$ dan terkecil terjadi tahun 2001 yaitu $20,47 \%$. Selanjutnya kontribusi yang diberikan pajak penerangan jalan terhadap PAD selama tahun 2001 sampai 2007 mempunyai rata-rata $15,56 \%$ atau termasuk kategori kurang. Kontribusi tertinggi terjadi tahun 2005 yaitu $17,95 \%$ dan kontribusi terkecil terjadi tahun 2001 yaitu $12,14 \%$. Secara umum, kontribusi pajak penerangan jalan terhadap pajak daerah dan PAD mempunyai pola yang sama, yaitu pada tahun 2001 sampai tahun 2005, kontribusinya terus meningkat tetapi pada tahun 2006 sampai 2007 kontribusinya terus menurun.

4) Berdasarkan hasil perkiraan dengan mengunakan analisis deret waktu, menunjukan bahwa penerimaan pajak penerangan jalan Kota Bandung pada tahun-tahun mendatang akan terus
meningkat.

Saran

Sesuai dengan hasil analisis dan kesimpulan, maka saran yang dapat diberikan penulis adala' sebagai berikut :

1) Pemerintah Kota Bandung, dalam melakukan pemungutan pajak penerangan jalan, yang menjadi tolok ukur keefektivitasan haruslah berpegang pada potensi riil dari penerimaan pajak tersebut. Karena selama ini, yang menjadi tolok ukur adalah target yang tidak mengacu
pada potensi riil dari penerimaan pajak tersebut

2) Dipenda harus melakukan langkah-langkah yang tepat dan khusus terhadap kondisi pajak penerangan jalan umumnya terhadap semua jenis pajak daerah. Karena pajak daerah, termasuk pajak penerangan jalan merupakan sumber penerimaan yang potensial dalam meningkatkan PAD. Diantaranya adalah dengan mengeluarkan kebijakan-kebijakan yang dapat meningkatkan PAD dan tidak berimbas negatif terhadap perekonomian serta lebih menjalin kerjasama dengan PT. PLN APJ Bandung (sebagai pihak pemungut pajak
penerangan jalan) yang menguntungkan kedua pihak.

Daftar Pustaka Abdul Halim. (2004). Bunga Rampai Manajemen Keuangan Daerah. Yogyakarta: UPP AMP
YKPN.

Abdul Majid. (2008). Peranan Pajak Daerah Dalam Rangka Peningkatan PAD. [Online]. Tersedia: http://majidbsz.wordpress.com/2008/06/30/peranan-pajak-daerah-dalam-rangka/.

Ahmad Yani. (2004) Hubungan Keuangan antara Pemerintah Pusat dan Pemerintah Daerah Di Indonesia. Jakarta: Raja Grafindo Persada.

Akhmad Rusyadi. (2005). Peranan Pajak Reklame Dalam Meningkatkan Pendapatan Asli Daerah di Kabupaten Brebes (2000-2004). Skripsi. Yogyakarta: Fakultas Ekonomi UII. 
Elita Dewi. (2002). Identifikasi Sumber-sumber Pendapatan Asli Daerah Dalam Rangka pelaksanaan Otonomi Daerah. [Online]. Tersedia: library.usu.ac.id/download/fisip/D0200232.pdf (10 Maret 2009).

Emilia Berti (2006). Mengukur Tingkat Kemampuan Keuangan Dalam Mendukung Pelaksanaan Otonomi Daerah Periode 2000-2004 Di Kabupaten Lampung Timur. Skripsi. Yogyakarta: FE Universitas Islam Indonesia.

Imelda Oktarianingsih (2003). Pajak Daerah dan Retribusi Daerah Di Kota Bandung: Elastisitas dan Upaya Pajak. Skripsi. Bandung: Universitas Padjajaran.

Iswardono (1992). Usaha Peningkatan PAD Daerah Kotamadya Yogya. Yogyakarta : BPFE.

Lembaga Penelitian dan Pengembangan (Litbang) Kota Bandung (2007). Resume Hasil Penelitian Kantor Litbang Kota Bandung Tahun 2006. [Online]. Tersedia : http://www.bandung.go.id/images/ragaminfo/daf_ringk_hsl__ penelitian2006.pdf. (27 Januari 2009)

Machfud Sidik. (2002). Optimalisasi pajak daerah dan retribusi daerah dalam rangka meningkatkan kemampuan keuangan daerah. [Online]. Tersedia: http://www.djpk.depkeu.go.id/publikasi/apbd/pajak-retribusi.pdf. (17 Februari 2009).

Mardismo. (2002). Otonomi dan Manajemen Keuangan Daerah. Yogyakarta: CV Andi.

Nick Devas et al. (1989). Keuangan Pemerintah Daerah Di Indonesia (Terjemahan Marsi Maris). Jakarta: UI Press.

Panjaitan Eviana Ulitaria. (2007). Tunggakan Pajak Reklame Bandung Rp 4,4 Miliar. Sindo. [Online]. Tersedia: http://www.Okezone.com/News. (21 Januari 2009).

Peraturan Daerah Kota Bandung No. 28 Tahun 2002 tertang Perubahan Peraturan Daerah Kodya Bandung No.20 Tahur 1998 tentang Pajak Penerangan Jalan.

Peraturan Pemerintah No. 58 Tahun 2005 tentang Pengelolaan Keuangan Daerah.

Peraturan Pemerintah No. 65 Tahun 2001 tentang Pajak Daerah.

Priyo Hari Adi. (2008). Relevansi Transfer Pemerintah Pusat Dengan Upaya Pajak Daerah. [Online]. Tersedia: http://pks l.wima.ac.id/pphks/accurate/ makalah/IE7.pdf. (26 Februari 2009).

PT. PLN (Persero) Distribusi Jawa Barat Cabang Bandung. (2005). Bandung Dalam Angka 2005. [Online]. Tersedia: http:/ www bandung.go.id/images/download/BAB6_BDA2005.pdf. (17 Februari 2009)

PT. PLN APJ Bandung. Rekapitulasi Pembuatan rekening Listrik Tahun 2001 sampai 2007. Tidak diterbitkan.

Sugiyono. (2007). Metode Penelitian Administrasi. Bandung: Alfabeta.

Undang-Undang No. 34 Tahun 2000 tentang Perubahan atas UU No.18 Tahun 1997 tentang Pajak Daerah dan Retribusi Daerah.

Virny Kumalasari. (2005). Analisis Faktor-faktor yang Mempengaruhi Penerimaan Fajak Penerangan Jalan Kelompok Rumah Tangga di Kota Surabaya. Skripsi. Surabaya: Fakultas Ekonomi Universitas Petra.

Yossi Irrianto. (2005). Optimalisasi Pajak dan Retribusi Daerah Dalam Rangka Meningkatkan Kemampuan Keuangan Daerah. Bandung: Dipenda Kota Bandung). 